\title{
Assessing the Impact of the EU-sponsored Trade Liberalization in the MENA Countries
}

\author{
Andrzej Cieślik \\ Warsaw University \\ Jan Hagemejer \\ National Bank of Poland \\ Warsaw University
}

\begin{abstract}
The EU-sponsored Barcelona conference in 1995 set the ambitious goal of creating the Euro-Mediterranean Free Trade Area (EUROMED) that would include the European Union and the MENA countries by 2010. The intermediate steps towards building the EUROMED have involved bilateral "vertical" trade liberalization between the EU and the particular MENA countries as well as "horizontal" trade liberalization among themselves. In this paper we evaluate empirically the effects of the new EU Association Agreements with the MENA countries using the augmented gravity equations derived from a variety of neoclassical and new trade theory models and panel data for the period 19802004. We find that while these agreements increased significantly imports of the MENA countries from the EU they had no positive impact on their exports to the $E U$ which can be attributed to the asymmetry in trade liberalization between the EU and the MENA countries.
\end{abstract}

\footnotetext{
*Corresponding address: Andrzej Cieslik: Macroeconomics and International Trade Theory Division, Department of Economics, Warsaw University, ul. Dluga 44/50, Warszawa, PL-00241, Poland, Tel: (48) 225549168, Fax: (48) 228312846, e-mail: cieslik@wne.uw.edu.pl, Jan Hagemejer: corresponding author: National Bank of Poland, Economic Institute, ul. Swietokrzyska 11/21, PL-00919, Poland, Tel: (48) 226531187, Fax: (48) 228269935, e-mail: jan.hagemejer@nbp.pl.
} 
- JEL Classification : F11, F12

- Key Words: bilateral trade, gravity equation, preferential trade liberalization

\section{Introduction}

The inability to achieve far reaching trade liberalization under the auspices of the General Agreement on Tariffs and Trade (GATT) and later the World Trade Organization (WTO) has led to the proliferation of regional trade agreements in the world trading system. According to the WTO convention, the term regional trade agreement (RTA) encompasses both reciprocal free trade or customs areas as well as plurilateral (multicountry) agreements. During the 1990s the European Union (EU) was a major player in the RTA game and an active sponsor of bilateral association agreements with its closest neighbours located in the Central and Eastern Europe (CEE) as well as in the Middle East and the North Africa (MENA).

The EU-sponsored Barcelona conference in 1995 set the ambitious goal of establishing the Euro-Mediterranean Free Trade Area (EUROMED) that would include the enlarged European Union and the MENA countries by 2010. The creation of the EUROMED is to be achieved by means of the new generation of the Euro-Mediterranean Association Agreements between the EU and the MENA countries accompanied by free trade agreements between the MENA countries themselves. In contrast to earlier, mostly non-reciprocal, trade liberalization the new Association Agreements provide for the implementation of bilateral free trade between the EU and the MENA countries.

In this paper we study the trade effects of the new EU Association Agreements for bilateral imports and exports of the MENA countries using the augmented gravity equation of international trade derived from a variety of neoclassical and new trade models. While there exists extensive literature that deals with evaluating empirically the effects of trade liberalization between the new and the old EU member states relatively little attention has been devoted to studying the effects of trade liberalization between the EU and the MENA countries.

Two main strands in the empirical trade literature employing gravity models in

${ }^{1}$ In addition to the gravity model based approach other approaches based on the CGE modeling have been extensively used to evaluate welfare effects of trade liberalization in the MENA countries. Examples of studies based on this approach include Maskus and Konan (1997), Augier and Gasiorek (2003), and Dennis (2006). 
the context of the MENA countries can be distinguished. ${ }^{1}$ The first, and the most numerous strand concentrates on estimating the trade potential of the MENA countries and predicting the volume of trade flows resulting from trade liberalization. Examples that belong to this strand include: Arnon et al. (1996), Ekholm et al. (1996), and more recently Nugent and Yousef (2005), Broto et al. (2006) and Tovias et al. (2007). Most of these studies find that the actual trade of MENA countries is below the predicted values and there exists unexploited trade potential.

Our study is related to the second, more recent strand that studies the ex-post consequences of trade liberalization in the MENA countries. This strand compared to the first one is still less numerous and the provided empirical evidence seems to be study-specific and dependent on the time period chosen. For example, AlAtrash and Yousef (2000) estimated the gravity equation using a pooled dataset for 18 Arab countries and their 43 partners during the period 1995-1997 to find that the estimated parameters on the dummy variable for the EU preferential arrangements were statistically significant but displayed counter-intuitive negative signs both in the case of exports and imports. ${ }^{2}$

More recently, Peridy (2005) estimated the gravity equation for 7 MENA countries and their 42 partner countries using a panel dataset for the period 19752001. He found that the EU trade preferences granted to the MENA countries increased their exports by about $20-27 \%$ depending on the model specification which evidences a significant gross trade creation. However, at the same time he noted that the positive trade preference impact has been steadily dropping over time. For example, the gross trade creation only from 1980 to 1995 decreased from 27.4 to $11.8 \%{ }^{3}$

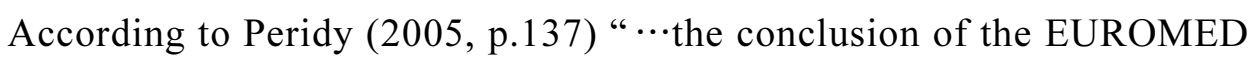
agreements should stop preference erosion in the future, unless the market access of Mediterranean agricultural imports remains restricted for a significant period of

${ }^{2}$ Al-Atrash and Yousef (2000, p. 12, fn. 8) do not, however, provide a convincing explanations for their findings and simply argue that this might be the results of capital flows or the time period chosen. In our view major trade liberalization in manufactured goods on the EU side took place much earlier than the period covered by their sample and its effects were no longer visible in the 1990s as shown later by Peridy (2005). At the same time the negative signs might be interpreted as the evidence of still existing trade restrictions both in the EU and the Arab countries

${ }^{3}$ Peridy (2005) attributes this decrease to three main factors: i) the restrictive EU trade policy regarding MENA agricultural export, ii) the removal of the Multifibre Agreement, and iii) the conclusion of the Europe Agreements between the EU and Central and Eastern European countries in the early 1990s that eroded MENA countries' trade preferences. 
time". However, no attempts have been made so far to evaluate empirically the effects of the new EU Association Agreements concluded with the MENA countries. Therefore, our study attempts to fill in a part of the existing gap in this important field of study by assessing empirically whether the new EU Association Agreements actually provided a new stimulus to the development of trade relations between the EU and the MENA countries.

Although the goal of our study may look similar to those of other studies focusing on evaluation ex-post effects of trade liberalization that can be found in the literature, three major differences with respect to the previous work can be identified. First, we use the generalized gravity equation that can be derived from a variety of neoclassical and new trade theory models and employ an empirical procedure that allows us to identify the appropriate model that explains the trade pattern of the MENA countries. Second, in our study while focusing on the effects of the new EU Association Agreements we control also for the effects of other both plurilateral and bilateral free trade agreements concluded by the MENA countries among themselves as well as with countries located outside the region. Third, we study the impact of the association agreements for both exports and imports separately for particular MENA countries as well as for the whole group.

We find that while the new EU Association Agreements increased significantly imports of the MENA countries from the EU, they did not contribute to the expansion of their exports to the EU markets. These findings can be explained by the asymmetry in trade liberalization between the EU and the MENA countries. On one hand, liberalization of the EU imports from the MENA countries was a gradual process that extended over the last thirty years and there was not much left to liberalize in the 1990s except for trade in agricultural goods which still remains very restricted. On the other hand, the MENA countries remained relatively closed to the EU exports, their initial level of protection was much higher than in the EU and liberalization of the MENA imports from the EU took place much faster and its scope was much bigger. Moreover, we find that the estimated impact of the new Association Agreements on bilateral trade of particular MENA countries differs greatly across the region.

The structure of this paper is as follows. In section II we provide a brief description of the history of trade liberalization in the MENA countries and the role of the EU in this process. In section III we present the analytical framework used for evaluating empirically the effects of preferential trade liberalization in the MENA countries. In section IV variables definitions and data sources are 
described. In section V estimation results for the whole MENA group as well as for particular countries of the MENA region are presented and discussed. Final remarks and policy guidelines are presented in the concluding section.

\section{Euro-Mediterranean Integration Process}

The integration of the MENA countries with the European Union has a long history that includes two generations of agreements ranging from unilateral preferences and non-reciprocal treatment to cooperation and association agreements. The main features of these agreements were the EU concessions in trade with the MENA countries. The first generation Euro-Mediterranean Association Agreements with the selected MENA countries that provided free access for their manufactures exports to the EU markets were concluded already in the 1960 s. $^{4}$

However, given the special historic, economic and political interest in the Mediterranean region, the European Commission launched in 1972 the Global Mediterranean Policy (GMP) that was aimed at providing non-discriminatory trade concessions to all MENA countries (Tovias, 1977). The main goal of this policy was to conclude a series of preferential trading agreements in industrial products between the EU and each MENA country and to offer concessions in agricultural imports to the EU that did not interfere with the European Common Agricultural Policy (CAP). ${ }^{5}$

Countries included in the GMP were the Maghreb countries (Morocco, Algeria and Tunisia), Mashreq countries (Egypt, Jordan, Lebanon and Syria), Israel, Libya, Turkey, Cyprus, Malta and the former Yugoslavia (Jovanoviæ, 2005). ${ }^{6}$ The GMP resulted in a series of the so-called Cooperation Agreements that were concluded with all the MENA countries between 1973 and 1980. The Cooperation Agreements extended earlier preferences for MENA exports of agricultural products both in terms of coverage and the margins of preference, however, at the same time these exports were subject to protectionist measures imposed by the

\footnotetext{
${ }^{4} \mathrm{In}$ addition to liberalization of manufactures goods imports from the associated countries some agricultural imports were granted reductions in the common external tariff.

${ }^{5}$ Euro-Mediterranean trade liberalization within the framework of the GPM was unilateral except for Israel where reciprocity was required. Most MENA markets remained protected by high tariffs until the middle of the 1990s.

${ }^{6}$ Greece, Spain and Portugal were also included in this policy before their entry into the EU in two ways of the Southern Enlargement that took place in 1981 (Greece) and in 1986 (Spain and Portugal).
} 
CAP.

Further liberalization of the EU imports from the MENA countries took place after the Southern enlargement in 1986 to include Spain and Portugal whose exports obtained unrestricted access to the EU markets. Following this enlargement the EU concluded a new series of agreements with the MENA countries called the Adaptation Agreements that were aimed at reducing increased tariff discrimination between those Mediterranean countries that joined the EU and those that stayed outside. As a result of this renovated policy by the end of 1993 all tariffs on exports from the MENA countries were eliminated, however, non-tariff barriers (NTBs) to trade related to the CAP were still in force.

The new round of trade liberalization between the EU and the MENA countries was initiated at the Euro-Mediterranean Conference of Ministers of Foreign Affairs held in Barcelona on 27-28 November 1995. In the Barcelona Declaration the EU and the MENA countries established the main objectives of the Barcelona Process, including the creation of the Euro-Mediterranean Free Trade Area by 2010. The Barcelona Process represents a turning point in the trade relations between the EU and the MENA countries as it means replacing the previous system of nonreciprocal preferences for most MENA countries by bilateral free trade agreements. $^{7}$

The Barcelona Process has two complementary dimensions: bilateral and regional. The EU carries out a number of activities bilaterally with each country. The most important ones are the Euro-Mediterranean Association Agreements that the European Commission negotiates individually with particular MENA countries. These new generation agreements that replaced the previous Association and Cooperation Agreements signed in the 1960s and 1970s foresee bilateral trade in manufactured goods and progressive liberalization of trade in agricultural products. ${ }^{8}$ The provisions of the Euro-Mediterranean Association Agreements

\footnotetext{
${ }^{7}$ Included with the EU member states in this potential agreements were the following Mediterranean countries: Algeria, Cyprus (the EU member since 2004), Egypt, Israel, Jordan, Lebanon, Malta (the EU member since 2004), Morocco, the Palestinian Authority, Syria, Tunisia and Turkey while Libya has the observer status since 1999. Together with the EFTA that forms together with the EU the European Economic Area, this zone is foreseen to become world's largest market place that will eventually include about 40 countries and 800 million consumers.

${ }^{8}$ However, the scope of trade liberalization in agricultural products is somewhat limited due to EU's refusal to remove NTBs on agricultural products. The major stumbling blocks in trade relations between the EU and the MENA countries was always the fact that they produce very similar agricultural commodities, such as wine, olive oil, citrus fruit and vegetables, to the ones produced in Southern Europe, in particular Greece, Italy, Southern France and Spain (Jovanovic, 2005).
} 
Table 1. The Euro-Mediterranean Association Agreements

\begin{tabular}{ccc}
\hline Country & Signature date & Entry into force \\
\hline Algeria & 22.04 .2002 & 01.09 .2005 \\
Egypt & 25.06 .2001 & 01.06 .2004 \\
Israel & 20.11 .1995 & 01.06 .2000 \\
Jordan & 24.11 .1997 & 01.05 .2002 \\
& & In process of ratification \\
Lebanon & 17.06 .2002 & (Interim Agreement for early implementation of \\
& & trade measures in force since 01.03.2003) \\
Morocco & 26.02 .1996 & 01.03 .2000 \\
Palestinian & 24.02 .1997 & 01.07 .1997 \\
Authority & Negotiations & \\
& (Interim association agreement) \\
Syria & concluded awaiting & \\
& for signature & \\
Tunisia & 17.07 .1995 & 01.03 .1998 \\
Turkey & 06.03 .1995 & 31.12 .1995 \\
\hline
\end{tabular}

Source: European Commission (2007). http://ec.europa.eu/external_relations/euromed/med_ass_agreements.htm

governing the bilateral relations contain the general principles common to all MENA countries as well as specific characteristics that vary across countries.

With the conclusion of negotiations with Syria in 2004 the network of bilateral Association Agreements with the MENA countries has been completed (see Table 1). After the signature the agreements entered a lengthy ratification process by the national parliaments of the EU member states and the MENA countries. The Association Agreements came progressively into force in Tunisia (1998), Israel (2000), Morocco (2000), Jordan (2002), Egypt (2004) and Algeria (2005). ${ }^{9}$

The Interim Agreements for early implementation of trade related matters are in force in the Palestinian Authority (1997) and Lebanon (2003). Moreover, special agreements establishing a customs union with the EU were signed with the European Mediterranean EU candidate countries: Cyprus, Malta and Turkey that entered into force before their accession into the EU. The EU enlargement on May 1, 2004 brought Cyprus and Malta into the EU, whereas the customs union agreement with Turkey (1996) is still in force.

In addition to "vertical" bilateral trade liberalization with the EU the MENA

\footnotetext{
${ }^{9}$ The implementation of the trade part of the Association Agreement with Israel started on January 1, 1996. In our econometric study presented further in the subsequent section we also used year 1989 as the date when unilateral liberalization of Israeli imports of manufactured goods from the EU took place, however, the estimation results were very similar.
} 
countries are committed to implement "horizontal" trade liberalization among themselves. However, compared to the Euro-Mediterranean Association Agreements radical trade liberalization between the MENA countries is still lagging behind. Some doubts about the desirability of intra-MENA trade liberalization stem from the long history of failure in creating a well functioning plurilateral free trade agreement.

Commonly mentioned examples of such failure stories include the Arab Common Market and other initiatives of the Arab League and the Council of Economic Unity, as well as various sub-regional arrangements such as among Maghreb countries, and many other trade agreements formed among countries of the MENA region. According to Nugent and Yousef $(2005$, p.1) "Not only have these special arrangements been far from fully realized, but also even normal trade among countries of the region has been periodically and unexpectedly interrupted by trade boycotts, ad hoc border closings and so on."

Given the lack of significant progress in liberalizing trade at the regional and sub-regional levels in the MENA region some countries located both in the Middle East and North Africa decided to liberalize their trade on a bilateral basis. This led to the establishment of the network of bilateral trade agreements by the end of the 1990s that prepared the ground for the Agadir Declaration signed in 2001 by the representatives of four MENA countries: Egypt, Jordan, Morocco and Tunisia. The Agadir Declaration included a commitment to the establishment of a free trade area (FTA) between these countries that remained open onto other Arab countries. ${ }^{10}$ In 2003 the four member countries of the Agadir group finalized the agreement on the establishment of a free trade area among themselves that would replace the existing bilateral trade agreements of the 1990s. The Agadir Agreement was signed in 2004 and was initially foreseen to take effect in 2005. However, due to the slow ratification process by some countries it has not entered into force until $2007 .^{11}$

\footnotetext{
${ }^{10}$ Lebanon and Syria are currently in the process of negotiations to join the Agadir Organization. Other potential entrants include Algeria, Libya, Mauritania and the Palestinian Authority.

${ }^{11}$ The declared goals of the Agadir Agreement in addition to the elimination of tariffs include also harmonization of laws in economic matters and coordination of sectoral and global economic policies, especially in the fields of international trade, agriculture, industry, finance, taxes and customs. A key element of the Agadir Agreement is the adoption of the Euro-Mediterranean Protocol on the rules of origin that allow MENA countries to benefit from the diagonal cumulation of value added. In contrast to the US rules of origin that consider value added domestically in the country that exports to the US this means that it turns the blind eye to where value was added for the purpose of preferential tariffs as long as it was in an FTA partner country. These conflicting regimes give the EU an advantage in its competition with the US to a secure the Euro-Mediterranean FTA as a counter force to the US-Middle East FTA.
} 
The Agadir Agreement is often perceived as a stepping stone to the formation of a well functioning regional trade agreement that would complement on-going "vertical" trade liberalization with the EU and eventually lead to the creation of the EUROMED. However, at this stage it is too early to evaluate its effectiveness. Nevertheless, it is possible to evaluate empirically at least the effectiveness of earlier bilateral trade agreements concluded among the MENA countries that laid the foundations for the Agadir Agreement. Therefore, in addition to studying the effects of the new EU Association Agreements we also study the effects of bilateral trade agreements of the Agadir countries concluded in the late 1990s.

\section{Analytical Framework}

To assess the effects of various preferential trading agreements concluded by the MENA countries we use a gravity equation of bilateral trade flows in its extended form that can be derived from a variety of neoclassical and new trade theory models. The gravity equation has been widely used in empirical studies of economic integration processes to investigate the changes in the geographic trade pattern and the effects of RTAs or currency unions on trade flows. However, most previous empirical studies employ the gravity equation in its simplified form that assumes complete specialization in production either at the country or the firm level and foresees no role for factor proportions. These simplistic equations predict that trade between two countries depends only on their economic size and trade costs between them.

In our view, while such equations may be appropriate for explaining trade flows between developed countries where most trade takes place in differentiated manufactured products, they cannot be regarded as fully satisfactory in explaining trade flows of the MENA countries which are on averaged still at the relatively low level of economic development and trade in homogenous agricultural goods constitutes an important part of their aggregate trade flows. Therefore, the estimates of the effects of RTAs obtained on the basis of such equations may be seriously biased due to the lack of controls for factor proportions that play a key role in the determination of trade flows in the incomplete specialization models especially when they are estimated for the middle- or low-income countries (Cieślik, 2007).

Moreover, in contrast to previous studies our empirical approach allows discriminating among alternative theories of international trade developed to 
explain the empirical success of the gravity equation. ${ }^{12}$ Our generalized estimating equation that encompasses specific estimating equations derived from a variety of theoretical models can be expressed in the logarithmic form as follows:

$$
\begin{aligned}
\ln V T_{i j t}= & \sum_{k=1}^{n} \beta_{k} R T A_{i j t}+\alpha_{1} \ln Y_{i t}+\alpha_{2} \ln Y_{j t}+\alpha_{3} \ln T_{i t} / L_{i t}+\alpha_{4} \ln T_{j t} / L_{j t} \\
& +\alpha_{5} \ln D I S T A N C E_{i j}+\alpha_{6} C_{\text {CONTIGUITY Y }}+\alpha_{7} A R A B I C_{i j}+\alpha_{8} \text { TURKISH }_{i j} \\
& +\alpha_{9} \operatorname{COLONY}_{i j}+\alpha_{10} \text { COLONIZER }_{i j}+u_{i}+u_{j}+u_{i j}+v_{t}+\varepsilon_{i j t}
\end{aligned}
$$

where: $V T_{i j t}$ is the value of trade flows (exports and imports, respectively) between countries $i$ and $j$ in year $t ; R T A_{i j t}$ is a dummy variable indicating whether countries $i$ and $j$ are both the members of a bilateral or a plurilateral regional preferential trading agreement in year $t ;^{13} Y_{i t}$ and $Y_{j t}$ are the levels of GDP in countries $i$ and $j$ in year $t$, respectively; $T_{i t} / L_{i t}$ and $T_{j t} / L_{j t}$ are the arable land per worker stocks in countries $i$ and $j$ in year $t$, respectively; DISTANCE $E_{i j}$ is the distance between countries $i$ and $j$; CONTIGUITY $i j$ is a dummy variable indicating whether countries $i$ and $j$ share a common border; $A R A B I C_{i j}$ and $T U R K I S H_{i j}$ is are two dummy variables indicating whether countries $i$ and $j$ share a common language; $C O L O N Y_{i j}$ is a dummy variable indicating whether countries $i$ and $j$ were in a colonial relationship; COLONIZER $R_{i j}$ is a dummy variable indicating whether countries $i$ and $j$ shared a common colonizer; $u_{i}$ and $u_{j}$ are the individual fixed effects for countries $i$ and $j$, respectively; $u_{i j}$ is the country-pair specific effect; $v_{t}$ is the time specific effect, and $\varepsilon_{i j t}$ is the error term that satisfies the standard properties.

The preferential trading agreements once implemented are expected to increase bilateral trade of both trading partners in the case of reciprocity, hence $\beta_{i}>0$ for all effective agreements. All theoretical models predict that trade flows should increase with the economic size of both trading partners, hence $\alpha_{1}, \alpha_{2}>0$. However, the impact of the factor proportion variables cannot be a priori determined as it varies across various theoretical models and could be either positive, negative or none depending of the extent of product differentiation. ${ }^{14}$

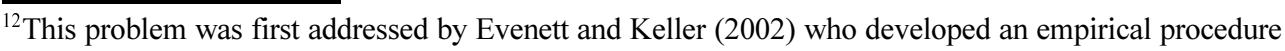
to discriminate among competing models that may provide theoretical foundations for the gravity equation. However, unlike Evenett and Keller (2002) we employ a alternative model identification procedure based on the signs and statistical significance of the estimated parameters on the factor proportion variables that is in our view more robust than the one proposed by Evenett and Keller (2002).

${ }^{13}$ The year of entry into force of a preferential trade agreement is used as a starting year for an RTA dummy variable.
} 
In particular, if both estimated parameters on the factor proportion variables display opposite signs and are statistically significant then trade of the MENA countries is explained by the standard Heckscher-Ohlin model with incomplete specialization in production. If only one of estimated parameters on factor proportion variables shows a positive sign and is statistically significant then their trade is explained by the Chamberlin-Heckscher-Ohlin model which is a hybrid of the $\mathrm{H}-\mathrm{O}$ and monopolistic competition models.

Finally, if none of the estimated parameters on the factor proportion variables is statistically significant then their trade is explained by one of complete specialization models: the $\mathrm{H}-\mathrm{O}$ or $\mathrm{C}-\mathrm{H}-\mathrm{O}$ models with complete specialization in production at the country level or the pure monopolistic competition model with complete specialization at the firm level. ${ }^{15}$ Therefore, the signs of the estimated parameters on the factor proportion variables $\alpha_{3}, \alpha_{4}$ and their statistical significance have to be determined empirically to identify the appropriate theoretical model that explains trade of the MENA countries.

Moreover, we expect trade flows to be negatively related to distance that serves as a proxy for transportation costs which should be low when countries are located close to each other, hence $\alpha_{5}<0$. Common border and language indicator variables also serve as proxy for transaction costs which should be lowered when trading partners share a common border or speak a common language, therefore $\alpha_{6}, \alpha_{7}, \alpha_{8}$ $>0$. The colonial ties serve as proxies for historical ties and should positively influence bilateral trade flows, hence $\alpha_{9}, \alpha_{10}>0$.

\section{Definitions of Variables and Data Sources}

Our dependent variables used in the estimating equation (1) are bilateral exports and imports of seven MENA countries that are the most advanced in liberalizing their trade with the EU as well as with each other. These include four North African countries: Algeria, Egypt, Morocco and Tunisia, and three countries

\footnotetext{
${ }^{14}$ For example, the standard Heckscher-Ohlin (H-O) model with homogenous goods as described by Jones (1965) predicts that bilateral imports of the land-abundant country increase with its land-labor ratio and decrease with land-labor ratio of the trading partner. In the Chamberlin-Heckscher-Ohlin (CH-O) model proposed by Helpman (1981) where one good is homogenous and the other differentiated bilateral imports of the land-abundant country also increase with its land-labor ratio while the landlabor ratio of the trading partner does not play any role in determination of the volume of imports. Finally, in the monopolistic competition model where all goods are differentiated land-labor ratios have no impact on the volume of trade.
} 
located in the Middle East: Israel, Jordan and Turkey. The sample choice has been determined by data availability. The trade flows data comes from the UN COMTRADE database and is expressed in the constant US dollars in 2000 prices. The trade data is available for 196 trading partners and covers the period of 19802004. This yields a total of almost 19 thousand observations. However, due to many missing observations our panel is unbalanced.

Our main explanatory variables include dummy variables indicating the new EU Association Agreements as well as dummy variables indicating the bilateral trade agreements between the Agadir countries discussed in detail in Section 2 that were in force for the time span covered by our sample. In addition to this in our study we control also for potential effects of other preferential trading agreements concluded by the MENA countries. These include: the EFTA agreements, the Arab Maghreb Union, the Arab Cooperation Council, various bilateral agreements between MENA countries as well as bilateral agreements with the EU associated states (now new EU member countries) in Central and Eastern Europe and the NAFTA countries: Canada, Mexico and the US. ${ }^{16}$

Most MENA countries in addition to the EU Association Agreements concluded at about the same time also free trade agreements with the EFTA countries that along with the EU form the European Economic Area since 1994. The EFTA agreements with the MENA countries that were in force during the period covered by our sample include Turkey (1992), Israel (1993), Morocco (1999), and Jordan (2002). ${ }^{17}$ In addition to the bilateral trade agreement between Israel and Turkey that is in force since 1997 these two countries concluded a number of bilateral agreements with the CEE countries most of which joined the EU in two subsequent waves of enlargement in 2004 and 2007.

Israeli free trade agreements with the CEE that entered into force include the agreements with the Czech and Slovak Republics (1997), Hungary (1998), Poland (1998), Slovenia (1998), Romania (2001) and Bulgaria (2002). Turkish free trade

\footnotetext{
${ }^{15}$ If this is the case then we need to consider alternative models that assume complete specialization either at the country or the firm level which lead to the same gravity equation (Deardorff, 1998). In this case the share of intra-industry trade can be used as an identification criterion to discriminate between alternative models (Evenett and Keller, 2002).

${ }^{16}$ In our study we take into account potential effects of preferential trading agreements at different stages of their implementation as some of these agreements despite their entry into force have not been fully implemented yet and much of the liberalizing effort is still to come.

${ }^{17}$ In addition to these, the EFTA concluded also other agreements with the MENA countries that include Tunisia (2005), the Palestinian Authority (1999), and Lebanon (2007). The agreement concluded with Egypt has not entered into force yet.
} 
agreements with the CEE countries that entered into force include the Czech and Slovak Republics (1998), Estonia (1998), Lithuania (1998), Hungary (1998), Romania (1998), Bulgaria (1999), Latvia (2000), Poland (2000), Slovenia (2000) and Croatia (2003). ${ }^{18}$

In our study we control also for the potential effects of plurilateral and bilateral trade agreements concluded among the MENA countries. The plurilateral agreements include the Arab Maghreb Union (AMU) and the Arab Cooperation Council (ACC). These are two sub-regional agreements established in 1989 in the MENA region. The AMU includes five North African countries: Algeria, Libya, Mauritania, Morocco and Tunisia while the ACC includes four countries located in the Middle East: Egypt, Iraq, Jordan and Yemen. Although none of these agreements was perceived as a successful in achieving trade liberalization the inclusion of AMU and ACC dummy variables allows controlling for regional differences between two main groups of countries in the MENA region: Maghreb and Mashreq. ${ }^{19}$

Given the failure of plurilateral trade liberalization at the sub-regional level some of the MENA countries decided to pursue trade liberalization on a bilateral basis. This resulted in a series of bilateral agreements concluded both between the MENA countries as well as with the countries outside the region. In this respect the most active countries in the region were Egypt and Jordan that liberalized trade not only among themselves but also with other MENA countries including two other future members of the Agadir group: Tunisia and Morocco, as well as with other Arab countries. ${ }^{20}$

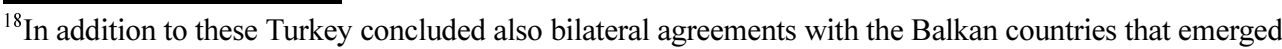
from the former Yugoslavia. These include the FTA with the FYR of Macedonia that entered into force in 2000 and was followed by the entry into force of the FTA with Bosnia-Hercegovina in 2003.

${ }^{19}$ The AMU was concluded with the aim to "...work gradually towards the realization of the freedom of movement of people, goods, services and capital" (Banks, 1995; p. 1030). The AMU was supposed to revive the old idea of regional integration in the Maghreb countries proposed already in the 1960s in the form of the Maghreb Customs Union (MCU) that was never implemented. However, despite the declared ambitious goals of the AMU that included the establishment of the free trade area in 1992, a common market by 2000 and eventually a monetary union, in 1993 leaders of the Maghreb countries agreed to postpone the discussion of the integration issues. Similar to the AMU, the ACC was formed in response to the slow pace of trade liberalization in the Arab countries and its intention was to revive regional integration in the Middle East proposed also in the 1960s in the form of the Arab Common Market (ACM) that has never been implemented despite some partial trade liberalization between 1965 and 1971. Similar to the AMU, also the ACC did not manage to achieve its the original goal of creating a sub-regional common market as a result of the political crisis that followed Iraq's invasion of Kuwait in 1990s.
} 
Finally, to complete the analysis of the impact of bilateral free trade agreements we also control for the agreements concluded by some MENA countries with the North American countries that formed the NAFTA. The agreements that were in force during the period of our investigation include the agreements concluded by Israel with the US (1985), Canada (1997) and Mexico (2000) as well as the agreement concluded by Jordan with the US (2001).

Our main control variables derived from the trade theory include two types of variables. The first refers to economic country size measures while the second to the measures of factor proportions. The country size is measured using the data on trading partners' GDPs expressed in constant 2000 US dollars and evaluated in the PPP terms to assure their cross country comparability. The GDP data comes from the World Development Indicators 2006 (WDI) database compiled and published on a CD-ROM by the World Bank in Washington. The land-labor ratios are approximated with arable land per capita which also comes from the WDI CDROM.

The remaining control variables include proxies for transportation and transaction costs. Distance between trading partners is measured as simple geographic "as the crow flies" distance between their capital cities and is expressed in kilometers. Distance data comes from the CEPII database available online at www.cepii.fr. In addition to the simple geographic proximity of trading partners we also include a dummy variable for the existence of a common border that takes the value 1 when countries share a common border, zero otherwise.

Following other studies we also include two dummy variables for a common language of trading partners. Language differences are often regarded as a major non-tariff barrier to trade. Since Arabic is the official language in all countries in the MENA region except Turkey we use a dummy variable that takes a value of 1 if Arabic is an official language in the partner country and zero otherwise. For Turkey we define a special dummy variable that takes a value of 1 if Turkish is an official language in the partner country and zero otherwise. ${ }^{21}$ Finally, to control for

\footnotetext{
${ }^{20}$ These four future members of the Agadir group by the end of the 1990s have established a network of bilateral trade agreements among themselves most of which entered into force in 1999. In addition to these agreements we take into account in our study also other agreements that entered into force concluded by Egypt with Syria (1991), and by Jordan with United Arab Emirates (2001), Bahrain (2002), Syria (2002), Sudan (2004). Other agreements that were in force but whose effectiveness cannot be verified empirically due to the lack of data include the agreements concluded by Egypt with Libya (1991), Lebanon (1995) and Iraq (2001), and by Jordan with Kuwait (2002) and Lebanon (2003).

${ }^{21}$ The only country except Turkey where Turkish is an official language is Cyprus.
} 
historical ties we include two dummy variables indicating whether trading countries were in a colonial relationship or had a common colonizer. Language and historical ties data also comes from the CEPII database available online at www.cepii.fr. The summary statistics are provided in the Appendix.

\section{Empirical Results}

In this section we present two sets of empirical results based on estimating equation (1) that include the averaged estimates for the whole MENA sample as well as the estimates obtained separately for particular MENA countries.

\section{A. Estimates for the Whole MENA Sample}

The estimation results for the whole MENA sample obtained using different estimation methods are reported in Table 2. The baseline estimates for bilateral imports and bilateral exports of the MENA countries obtained using the fixed effects estimation method that allows controlling for country-pair specific effects as well as individual time effects for particular years of our sample are reported in columns (1) and (4), respectively. ${ }^{22}$ The estimation results show that both in the case of imports and exports of the MENA countries the estimated parameters on the indicator variables for the new EU Association Agreements are statistically significant already at the 1 percent level.

However, while the estimated parameter on the EU dummy in the case of imports displays a positive sign, it is negative in the case of exports. This finding confirms the frequently expressed opinion that while the new EU Association Agreements provided a new stimulus to the development of trade between the EU and the MENA countries it was only due to the opening of the MENA markets to the manufactured goods produced in the EU. The negative sign on the EU dummy variable in the case of MENA exports to the EU clearly indicates the presence of barriers to trade on the EU side as trade in agricultural goods in which the MENA countries have a comparative advantage still remains very restricted.

Very similar results can be reported for the case of free trade agreements concluded with the EFTA countries where trade in agricultural goods has not also

\footnotetext{
${ }^{22}$ This estimation method is appropriate for a heterogenous panel with country fixed effects as these represent the effects of trade resistance, as well as other omitted effects such as differences in exchange rate regimes. The F-test for time specific effects confirms the appropriateness of including time dummies for particular years of our sample, while the Hausman test advocates the use of fixed effects instead of random effects in all estimated regressions for the whole MENA sample.
} 
Table 2. Panel Estimates for the Whole MENA Sample

\begin{tabular}{|c|c|c|c|c|c|c|}
\hline & \multicolumn{3}{|c|}{ Import } & \multicolumn{3}{|c|}{ Export } \\
\hline & 1 & 2 & 3 & 4 & 5 & 6 \\
\hline Coefficient & $\mathrm{FE}$ & $2 \mathrm{FE}$ & D2FE & $\mathrm{FE}$ & $2 \mathrm{FE}$ & D2FE \\
\hline \multirow{2}{*}{$\begin{array}{l}\text { EU-Association } \\
\text { Agreement }\end{array}$} & $0.244^{* * *}$ & $0.376^{* * *}$ & $0.375^{* * *}$ & $-0.297^{* * *}$ & $-0.258^{* * *}$ & -0.151 \\
\hline & {$[0.08]$} & {$[0.09]$} & [0.09] & [0.08] & {$[0.10]$} & {$[0.10]$} \\
\hline \multirow[t]{2}{*}{ EFTA } & $0.332^{* *}$ & $0.999^{* * *}$ & $0.886^{* * *}$ & $-0.417^{* *}$ & 0.137 & 0.157 \\
\hline & {$[0.17]$} & {$[0.18]$} & {$[0.17]$} & {$[0.17]$} & {$[0.20]$} & {$[0.19]$} \\
\hline \multirow[t]{2}{*}{ CEE } & $0.632^{* * *}$ & $0.596^{* * *}$ & $0.532^{* * *}$ & $0.653^{* * *}$ & $0.582^{* * *}$ & $0.560^{* * * *}$ \\
\hline & {$[0.19]$} & [0.19] & {$[0.18]$} & {$[0.20]$} & {$[0.21]$} & {$[0.20]$} \\
\hline \multirow[t]{2}{*}{ NAFTA } & -0.144 & $0.750^{* *}$ & $0.756^{* * *}$ & 0.337 & 0.525 & $0.633^{* *}$ \\
\hline & {$[0.36]$} & {$[0.31]$} & {$[0.29]$} & {$[0.38]$} & {$[0.34]$} & {$[0.32]$} \\
\hline \multirow[t]{2}{*}{$\mathrm{AMU}$} & $0.688^{* * *}$ & 0.183 & -0.160 & $1.110^{* * *}$ & $1.083^{* * *}$ & $0.731^{* * *}$ \\
\hline & {$[0.22]$} & {$[0.20]$} & {$[0.19]$} & {$[0.22]$} & {$[0.21]$} & {$[0.20]$} \\
\hline \multirow[t]{2}{*}{$\mathrm{ACC}$} & 0.851 & 0.501 & 0.269 & 0.874 & 0.528 & 0.269 \\
\hline & {$[0.74]$} & [0.89] & {$[0.82]$} & {$[0.76]$} & {$[0.96]$} & {$[0.91]$} \\
\hline \multirow[t]{2}{*}{ Israel-Turkey } & $1.318^{* * *}$ & $1.900^{* * *}$ & $1.906^{* * *}$ & $0.828^{*}$ & 0.585 & 0.688 \\
\hline & {$[0.42]$} & {$[0.46]$} & {$[0.43]$} & {$[0.44]$} & {$[0.50]$} & {$[0.47]$} \\
\hline \multirow[t]{2}{*}{ Jordan-Morocco } & $1.032^{* *}$ & 0.622 & 0.429 & 0.518 & 0.659 & 0.542 \\
\hline & {$[0.46]$} & {$[0.52]$} & {$[0.48]$} & {$[0.48]$} & {$[0.57]$} & {$[0.54]$} \\
\hline \multirow[t]{2}{*}{ Morocco-Tunisia } & -0.405 & 0.778 & $0.979^{*}$ & $-1.040^{* *}$ & -0.587 & -0.359 \\
\hline & {$[0.47]$} & {$[0.54]$} & {$[0.50]$} & {$[0.49]$} & {$[0.59]$} & {$[0.56]$} \\
\hline \multirow[t]{2}{*}{ Egypt-Syria } & -0.101 & 0.391 & 0.682 & -0.518 & 0.816 & $1.097^{* *}$ \\
\hline & {$[0.46]$} & {$[0.52]$} & {$[0.48]$} & {$[0.48]$} & {$[0.57]$} & {$[0.53]$} \\
\hline \multirow[t]{2}{*}{ Egypt-Jordan } & 0.471 & 0.337 & 0.328 & -0.0233 & -0.136 & -0.0539 \\
\hline & {$[0.47]$} & {$[0.52]$} & {$[0.48]$} & {$[0.48]$} & {$[0.57]$} & {$[0.54]$} \\
\hline \multirow[t]{2}{*}{ Egypt-Morocco } & $0.984^{* *}$ & 0.368 & 0.420 & 0.607 & $1.077^{*}$ & $1.119^{* *}$ \\
\hline & {$[0.46]$} & {$[0.52]$} & {$[0.48]$} & {$[0.48]$} & {$[0.57]$} & {$[0.54]$} \\
\hline \multirow[t]{2}{*}{ Jordan-Tunisia } & -0.0404 & 0.685 & 0.731 & -0.595 & 0.470 & 0.595 \\
\hline & {$[0.46]$} & {$[0.52]$} & {$[0.48]$} & {$[0.48]$} & {$[0.57]$} & {$[0.54]$} \\
\hline \multirow{2}{*}{$\begin{array}{l}\text { Other Arab } \\
\text { Agreements }\end{array}$} & 0.352 & 0.340 & 0.335 & $0.773^{* * *}$ & $0.609^{*}$ & $0.727^{* *}$ \\
\hline & {$[0.28]$} & {$[0.30]$} & {$[0.28]$} & {$[0.28]$} & {$[0.33]$} & {$[0.31]$} \\
\hline \multirow[t]{2}{*}{$Y_{i}$ (partner) } & $1.280^{* * *}$ & $1.198^{* * *}$ & -0.0120 & $0.824^{* * *}$ & $0.785^{* * *}$ & 0.276 \\
\hline & {$[0.07]$} & {$[0.09]$} & [0.27] & {$[0.07]$} & {$[0.10]$} & {$[0.28]$} \\
\hline \multirow[t]{2}{*}{$Y_{j}$ (reporting) } & $2.252^{* * *}$ & $1.697^{* * *}$ & $1.563^{* * *}$ & $2.832^{* * *}$ & $2.732^{* * *}$ & -0.446 \\
\hline & {$[0.17]$} & {$[0.20]$} & {$[0.38]$} & {$[0.18]$} & {$[0.22]$} & {$[0.42]$} \\
\hline \multirow[t]{2}{*}{$(T / L)_{i}$ (partner) } & $-0.268^{* * *}$ & $-0.327^{* * *}$ & $-0.523^{* * *}$ & $-0.442^{* * *}$ & $-0.419^{* * *}$ & $-0.587^{* * *}$ \\
\hline & {$[0.09]$} & {$[0.11]$} & {$[0.11]$} & {$[0.09]$} & {$[0.11]$} & {$[0.12]$} \\
\hline \multirow[t]{2}{*}{$(T / L)_{j}$ (reporting) } & $0.538^{* * *}$ & $0.820^{* * *}$ & $0.562^{* * *}$ & 0.0683 & 0.101 & -0.00933 \\
\hline & {$[0.12]$} & {$[0.14]$} & {$[0.14]$} & {$[0.13]$} & {$[0.16]$} & [0.16] \\
\hline \multirow[t]{2}{*}{$D_{I S T A N C E} E_{i j}$} & & $-0.792^{* * *}$ & $-0.831^{* * *}$ & & $-1.484^{* * *}$ & $-1.543^{* * *}$ \\
\hline & & {$[0.04]$} & {$[0.04]$} & & {$[0.05]$} & {$[0.05]$} \\
\hline
\end{tabular}


Table 2. Panel Estimates for the Whole MENA Sample(continued)

\begin{tabular}{|c|c|c|c|c|c|c|}
\hline & \multicolumn{3}{|c|}{ Import } & \multicolumn{3}{|c|}{ Export } \\
\hline & 1 & 2 & 3 & 4 & 5 & 6 \\
\hline Coefficient & $\mathrm{FE}$ & $2 \mathrm{FE}$ & $\mathrm{D} 2 \mathrm{FE}$ & $\mathrm{FE}$ & $2 \mathrm{FE}$ & $\mathrm{D} 2 \mathrm{FE}$ \\
\hline \multirow[t]{2}{*}{$\overline{C O N T I G U I T Y_{i j}}$} & & $0.793^{* * *}$ & $0.804^{* * *}$ & & -0.0533 & -0.0624 \\
\hline & & [0.11] & {$[0.11]$} & & [0.12] & [0.12] \\
\hline \multirow[t]{2}{*}{$C O L O N Y_{i j}$} & & $0.304^{* * *}$ & $0.260^{* *}$ & & $0.683^{* * *}$ & $0.648^{* * *}$ \\
\hline & & {$[0.11]$} & {$[0.10]$} & & {$[0.12]$} & [0.11] \\
\hline \multirow[t]{2}{*}{$C^{C O L O N I Z E R_{i j}}$} & & $0.669^{* * *}$ & $0.826^{* * *}$ & & $0.432^{* * *}$ & $0.499^{* * *}$ \\
\hline & & {$[0.06]$} & {$[0.06]$} & & {$[0.06]$} & {$[0.06]$} \\
\hline \multirow[t]{2}{*}{$A R A B I C_{i j}$} & & $0.855^{* * *}$ & $0.683^{* * *}$ & & $0.882^{* * *}$ & $0.799^{* * *}$ \\
\hline & & {$[0.06]$} & {$[0.06]$} & & {$[0.06]$} & {$[0.06]$} \\
\hline \multirow[t]{2}{*}{ TURKISH $_{i j}$} & & $-1.752^{* * *}$ & $-1.342^{* * *}$ & & $-0.797^{*}$ & -0.418 \\
\hline & & {$[0.41]$} & {$[0.40]$} & & {$[0.43]$} & {$[0.41]$} \\
\hline \multirow[t]{2}{*}{ Constant } & $-78.71^{* * *}$ & $-57.21^{* * *}$ & 17.27 & $-84.01^{* * *}$ & $-69.48^{* * *}$ & $11.79^{* * *}$ \\
\hline & {$[4.50]$} & {$[5.61]$} & [3.02] & [4.73] & [6.39] & [1.10] \\
\hline Observations & 18190 & 18190 & 15972 & 18503 & 18503 & 16272 \\
\hline$R$-squared & 0.37 & 0.74 & 0.75 & 0.25 & 0.69 & 0.69 \\
\hline Hausman & $211.3^{* * *}$ & & & $111.5^{* * *}$ & & \\
\hline $\begin{array}{l}F \text { test for Fixed } \\
\text { Effects }\end{array}$ & $22.59^{* * *}$ & $49.42^{* * *}$ & $194.5^{* * *}$ & $22.20^{* * *}$ & $33.18^{* * *}$ & $149.5^{* * *}$ \\
\hline $\begin{array}{l}F \text { test for Time } \\
\text { Dummies }\end{array}$ & $7.471^{* * *}$ & $3.520^{* * *}$ & $5.502^{* * *}$ & $6.878^{* * *}$ & $3.841^{* * *}$ & $8.717^{* * *}$ \\
\hline
\end{tabular}

Notes: Robust standard errors in brackets, ${ }^{* * *} p<0.01,{ }^{* *} p<0.05,{ }^{*} p<0.1$

been liberalized. Interestingly, in the case of free trade agreements concluded by Israel and Turkey with the Central and Eastern European EU candidate countries the estimated parameters on the CEE dummy both in the case of imports and exports are statistically significant and display positive signs. ${ }^{23}$

The parameter estimates on the intra-MENA agreements are mostly not statistically significant, which confirms the general view that trade between these countries still remains restricted, although some exceptions can be identified. In particular, among the plurilateral intra-MENA agreements only the parameter on

\footnotetext{
${ }^{23}$ This result might be due to the fact that while trade liberalization with Western Europe was a gradual process that extended over several decades trade with Central and Eastern European countries that remained isolated from the world economy for almost fifty years after the World War II has been liberalized only recently which led to substantial trade creation.

${ }^{24}$ This result is surprising given the fact that the Arab Maghreb Union was never fully implemented. Perhaps, our dummy variable for the Arab Maghreb Union captures some other effects common to these countries, such as political and cultural proximity, the positively affect their bilateral trade flows which we were not able to control for using the standard set of explanatory variables.
} 
the Arab Maghreb Union dummy variable is statistically significant at the 1 percent level both in the case of imports and exports. ${ }^{24}$ Among the bilateral intra-MENA agreements only the parameters on Israel-Turkey agreement is statistically significant at the 1 percent level, and only in the case of imports.

Moreover, it is worth noting that the estimated parameters on both factor proportion variables and statistically significant at the 1 percent level and display the opposite signs. This finding supports the general view that the standard Heckscher-Ohlin model with incomplete specialization in production does well in explaining foreign trade of the MENA countries which is still dominated by the inter-industry rather than intra-industry exchange.

The robustness of our baseline estimates is subsequently investigated in the remaining columns of Table 2 . It has been frequently argued that the fixed effects estimation method that controls for country-pair specific effects might not be fully correct and specific effects separately for trading countries must be taken into account (Matyas, 1997). The estimation results obtained via the two-way fixed effects estimation method for imports and exports of the MENA countries are reported in columns (2) and (5), respectively. However, compared to the baseline results presented in columns (1) and (4), very little difference can be seen and our major conclusions concerning the signs and statistical significance of the estimated parameters on the key explanatory variables remain unchanged.

Finally, in columns (3) and (6) we report the estimation results for imports and exports, respectively, obtained using two-way fixed effects for the specification where the GDP series for both trading countries were expressed in first differences to address the non-stationarity problem. However, these changes in the specification of our estimating equation had no impact on our major conclusions. This means that the EU countries, at least in the short-run, are the main beneficiaries of the new EU Association Agreements and the pattern of trade of the MENA countries can be well explained by the standard Heckscher-Ohlin model.

\section{B. Estimates for Particular MENA Countries}

To gain a deeper insight into what drives our empirical results we split our sample into seven sub-samples for the particular MENA countries and estimate the gravity equations for their bilateral exports and imports separately for each country using the fixed effects estimator that allows controlling for the individual fixed effects for the partner country. ${ }^{25}$ The estimation results for bilateral imports of the

\footnotetext{
${ }^{25}$ Time dummies are not included due to the perfect collinearity with the reporting country's GDP.
} 
Assessing the Impact of the EU-sponsored Trade Liberalization in the MENA Countries 361

Table 3. Fixed Effects Estimates for Bilateral Imports of Particular MENA Countries

\begin{tabular}{|c|c|c|c|c|c|c|c|}
\hline Coefficient & Algeria & Egypt & Israel & Jordan & Morocco & Tunisia & Turkey \\
\hline $\begin{array}{l}\text { EU-Association } \\
\text { Agreement }\end{array}$ & & $-0.346^{* * *}$ & -0.004 & 0.030 & $0.376^{* * *}$ & $0.279^{* * *}$ & $0.356^{* * *}$ \\
\hline & & [0.11] & {$[0.08]$} & {$[0.10]$} & {$[0.10]$} & {$[0.09]$} & {$[0.08]$} \\
\hline EFTA & & & 0.059 & -0.628 & $0.926^{* * *}$ & & -0.061 \\
\hline & & & {$[0.13]$} & {$[0.46]$} & {$[0.29]$} & & {$[0.16]$} \\
\hline CEE & & & $\begin{array}{l}0.288^{* * *} \\
{[0.11]}\end{array}$ & & & & $\begin{array}{l}0.455^{* * *} \\
{[0.13]}\end{array}$ \\
\hline NAFTA & & & $\begin{array}{l}-0.378^{* * *} \\
{[0.09]}\end{array}$ & $\begin{array}{l}-0.362^{* * *} \\
{[0.11]}\end{array}$ & & & \\
\hline AMU & $\begin{array}{l}0.855 \\
{[0.61]}\end{array}$ & & & & $\begin{array}{l}1.291^{* *} \\
{[0.52]}\end{array}$ & $\begin{array}{l}0.282 \\
{[0.34]}\end{array}$ & \\
\hline ACC & & $\begin{array}{l}1.344^{* * *} \\
{[0.38]}\end{array}$ & & $\begin{array}{l}0.185 \\
{[0.19]}\end{array}$ & & & \\
\hline Israel-Turkey & & & $\begin{array}{l}1.551^{* * *} \\
{[0.17]}\end{array}$ & & & & $\begin{array}{l}0.343^{* *} \\
{[0.14]}\end{array}$ \\
\hline Jordan-Morocco & & & & $\begin{array}{l}0.538^{* * *} \\
{[0.18]}\end{array}$ & $\begin{array}{l}1.187^{* * *} \\
{[0.46]}\end{array}$ & & \\
\hline Morocco-Tunisia & & & & & $\begin{array}{l}-0.449 \\
{[0.28]}\end{array}$ & $\begin{array}{l}-0.226 \\
{[0.19]}\end{array}$ & \\
\hline Egypt-Syria & & $\begin{array}{l}0.393^{* *} \\
{[0.19]}\end{array}$ & & & & $\begin{array}{l}0.193 \\
{[0.14]}\end{array}$ & \\
\hline Egypt-Jordan & & $\begin{array}{l}0.872^{* * *} \\
{[0.34]}\end{array}$ & & $\begin{array}{l}0.611^{* *} \\
{[0.26]}\end{array}$ & & & \\
\hline Egypt-Morocco & & $\begin{array}{l}1.080^{* * *} \\
{[0.22]}\end{array}$ & & & $\begin{array}{l}1.175^{* * *} \\
{[0.25]}\end{array}$ & & \\
\hline Jordan-Tunisia & & & & $\begin{array}{l}-0.899^{* * *} \\
{[0.27]}\end{array}$ & & $\begin{array}{l}1.456^{* *} \\
{[0.58]}\end{array}$ & \\
\hline $\begin{array}{l}\text { Other Arab } \\
\text { Agreements }\end{array}$ & & $0.860^{* * *}$ & & $0.514^{* *}$ & -0.137 & & \\
\hline & & [0.32] & & {$[0.23]$} & {$[0.55]$} & & \\
\hline$Y_{i}$ (partner) & $\begin{array}{l}1.405^{* * *} \\
{[0.26]}\end{array}$ & $\begin{array}{l}0.848^{* * *} \\
{[0.20]}\end{array}$ & $\begin{array}{l}1.659^{* * *} \\
{[0.24]}\end{array}$ & $\begin{array}{l}1.005^{* * *} \\
{[0.19]}\end{array}$ & $\begin{array}{l}0.923^{* * *} \\
{[0.18]}\end{array}$ & $\begin{array}{l}1.607^{* * *} \\
{[0.24]}\end{array}$ & $\begin{array}{l}1.308^{* * *} \\
{[0.24]}\end{array}$ \\
\hline$Y_{j}$ (reporting) & $\begin{array}{l}3.745^{* * *} \\
{[0.76]}\end{array}$ & $\begin{array}{l}0.205 \\
{[0.21]}\end{array}$ & $\begin{array}{l}0.219 \\
{[0.59]}\end{array}$ & $\begin{array}{l}0.664^{* *} \\
{[0.31]}\end{array}$ & $\begin{array}{l}0.910^{* * *} \\
{[0.33]}\end{array}$ & $\begin{array}{l}-0.642 \\
{[0.41]}\end{array}$ & $\begin{array}{l}4.193^{* * *} \\
{[0.56]}\end{array}$ \\
\hline$(T / L)_{i}$ (partner) & $\begin{array}{l}0.204 \\
{[0.29]}\end{array}$ & $\begin{array}{l}-0.172 \\
{[0.22]}\end{array}$ & $\begin{array}{l}-0.285 \\
{[0.26]}\end{array}$ & $\begin{array}{l}-0.475^{* *} \\
{[0.20]}\end{array}$ & $\begin{array}{l}-0.890^{* * *} \\
{[0.22]}\end{array}$ & $\begin{array}{l}0.145 \\
{[0.22]}\end{array}$ & $\begin{array}{l}-0.152 \\
{[0.25]}\end{array}$ \\
\hline $\begin{array}{l}(T / L)_{j}(\text { report- } \\
\text { ing) }\end{array}$ & $6.964^{* * *}$ & $1.048^{* *}$ & -0.437 & $1.015^{* * *}$ & $1.846^{* *}$ & -0.183 & $5.477^{* * *}$ \\
\hline & {$[1.08]$} & {$[0.53]$} & {$[1.09]$} & {$[0.20]$} & [0.81] & {$[0.64]$} & {$[1.05]$} \\
\hline Constant & $\begin{array}{c}-111.00^{* * *} \\
{[18.4]}\end{array}$ & $\begin{array}{l}-18.51^{* * *} \\
{[3.03]}\end{array}$ & $\begin{array}{l}-40.41^{* * *} \\
{[12.9]}\end{array}$ & $\begin{array}{l}-29.95^{* * *} \\
{[6.99]}\end{array}$ & $\begin{array}{l}-38.09^{* * *} \\
{[7.29]}\end{array}$ & $\begin{array}{l}-14.18 \\
{[8.64]}\end{array}$ & $\begin{array}{c}-130.70^{* * *} \\
{[14.7]}\end{array}$ \\
\hline Observations & 2554 & 2720 & 2339 & 2294 & 2732 & 2676 & 2875 \\
\hline
\end{tabular}


Table 3. Fixed Effects Estimates for Bilateral Imports of Particular MENA Countries (continued)

\begin{tabular}{lccccccc}
\hline \multicolumn{1}{c}{ Coefficient } & Algeria & Egypt & Israel & Jordan & Morocco & Tunisia & Turkey \\
\hline$R$-squared & 0.78 & 0.85 & 0.89 & 0.86 & 0.82 & 0.83 & 0.86 \\
$F$ test for Fixed & $1441^{* * *}$ & $199.3^{* * *}$ & $62185^{* * *}$ & $20016^{* * *}$ & $5086^{* * *}$ & $821.7^{* * *}$ & $827.7^{* * *}$ \\
Effects & & & & & & & \\
\hline
\end{tabular}

Robust standard errors in brackets, ${ }^{* * *} \mathrm{p}<0.01,{ }^{* *} \mathrm{p}<0.05,{ }^{*} \mathrm{p}<0.1$

individual MENA countries are presented in Table 3 while for bilateral exports in Table 4.

We find that the estimated trade effects of the new EU Association Agreements are not the same for all MENA countries and significant heterogeneity between them exists. In the case of bilateral imports we obtained positive and statistically significant coefficients of the indicator variables for the new EU Association Agreements only for Morocco, Tunisia and Turkey. The estimated parameters on

Table 4. Fixed Effects Estimates for Bilateral Exports of Particular MENA Countries

\begin{tabular}{|c|c|c|c|c|c|c|c|}
\hline COEFFICIENT & Algeria & Egypt & Israel & Jordan & Morocco & Tunisia & Turkey \\
\hline $\begin{array}{l}\text { EU-Association } \\
\text { Agreement }\end{array}$ & & -0.211 & $-0.459^{* * *}$ & -0.041 & $-0.367^{* * *}$ & $-0.263^{* *}$ & $-0.423^{* * *}$ \\
\hline & & {$[0.28]$} & {$[0.07]$} & {$[0.21]$} & {$[0.10]$} & {$[0.11]$} & {$[0.06]$} \\
\hline EFTA & & & $\begin{array}{c}-0.588^{* * *} \\
{[0.09]}\end{array}$ & $\begin{array}{c}-1.406^{* * *} \\
{[0.49]}\end{array}$ & $\begin{array}{l}-0.293^{* *} \\
{[0.14]}\end{array}$ & & $\begin{array}{l}-0.482^{* * *} \\
{[0.12]}\end{array}$ \\
\hline CEE & & & $\begin{array}{c}0.122 \\
{[0.10]}\end{array}$ & & & & $\begin{array}{l}0.398^{* * *} \\
{[0.10]}\end{array}$ \\
\hline NAFTA & & & $\begin{array}{l}-0.011 \\
{[0.07]}\end{array}$ & $\begin{array}{l}2.460^{* * *} \\
{[0.23]}\end{array}$ & & & \\
\hline AMU & $\begin{array}{c}1.793^{* * *} \\
{[0.59]}\end{array}$ & & & & $\begin{array}{l}1.713^{* * *} \\
{[0.48]}\end{array}$ & $\begin{array}{l}0.458^{*} \\
{[0.24]}\end{array}$ & \\
\hline $\mathrm{ACC}$ & & $\begin{array}{l}0.509^{* *} \\
{[0.23]}\end{array}$ & & $\begin{array}{c}1.153^{* * *} \\
{[0.37]}\end{array}$ & & & \\
\hline Israel-Turkey & & & $\begin{array}{l}0.516^{* * *} \\
{[0.10]}\end{array}$ & & & & $\begin{array}{l}0.862^{* * *} \\
{[0.12]}\end{array}$ \\
\hline Jordan-Morocco & & & & $\begin{array}{c}1.269^{* *} \\
{[0.51]}\end{array}$ & $\begin{array}{c}-0.498^{* *} \\
{[0.22]}\end{array}$ & & \\
\hline
\end{tabular}

\footnotetext{
${ }^{26}$ These results are not surprising given the fact that the EU Association Agreements with Jordan (2002) and Egypt (2004) went into force only recently and it is well known that the effects of free trade agreements are not immediate and often come with a few year delay from the dates of their entry into force. In the case of Israel most trade with the EU was liberalized a long time ago and no additional stimulus was provided in the 1990s. h the reporting country's GDP.
} 
Table 4. Fixed effects estimates for bilateral exports of particular MENA countries (continued)

\begin{tabular}{|c|c|c|c|c|c|c|c|}
\hline COEFFICIENT & Algeria & Egypt & Israel & Jordan & Morocco & Tunisia & Turkey \\
\hline \multirow[t]{2}{*}{ Morocco-Tunisia } & & & & & $-1.690^{* * * *}$ & -0.181 & \\
\hline & & & & & {$[0.34]$} & {$[0.17]$} & \\
\hline \multirow[t]{2}{*}{ Egypt-Syria } & & $-0.610^{* * *}$ & & & & -0.113 & \\
\hline & & {$[0.13]$} & & & & [0.21] & \\
\hline \multirow[t]{2}{*}{ Egypt-Jordan } & & $-0.668^{* *}$ & & 0.402 & & & \\
\hline & & {$[0.33]$} & & {$[0.31]$} & & & \\
\hline \multirow[t]{2}{*}{ Egypt-Morocco } & & $0.562^{* *}$ & & & $0.605^{* * *}$ & & \\
\hline & & {$[0.25]$} & & & {$[0.22]$} & & \\
\hline \multirow[t]{2}{*}{ Jordan-Tunisia } & & & & 0.749 & & $-1.459^{* * *}$ & \\
\hline & & & & {$[0.54]$} & & {$[0.30]$} & \\
\hline \multirow[t]{2}{*}{$\begin{array}{l}\text { Other Arab } \\
\text { Agreements }\end{array}$} & & $2.249^{* * *}$ & & $-0.273^{*}$ & $0.544^{* * *}$ & & \\
\hline & & {$[0.51]$} & & {$[0.14]$} & {$[0.20]$} & & \\
\hline \multirow[t]{2}{*}{$Y_{i}$ (partner) } & $1.743^{* * *}$ & 0.252 & $1.240^{* * *}$ & $0.976^{* * *}$ & $0.839^{* * *}$ & $1.007^{* * *}$ & 0.199 \\
\hline & {$[0.39]$} & {$[0.20]$} & {$[0.19]$} & {$[0.25]$} & {$[0.13]$} & {$[0.23]$} & {$[0.15]$} \\
\hline \multirow[t]{2}{*}{$Y_{j}$ (reporting) } & -0.0937 & $2.039^{* * *}$ & -0.0356 & $0.947^{* *}$ & 0.467 & 0.498 & $1.949^{* * *}$ \\
\hline & [1.09] & {$[0.23]$} & {$[0.47]$} & {$[0.40]$} & {$[0.30]$} & [0.44] & {$[0.41]$} \\
\hline \multirow[t]{2}{*}{$(T / L)_{i}$ (partner) } & -0.423 & $-1.199^{* * *}$ & $0.546^{* *}$ & -0.407 & $-1.084^{* * *}$ & -0.111 & -0.051 \\
\hline & {$[0.51]$} & {$[0.22]$} & {$[0.22]$} & {$[0.26]$} & {$[0.19]$} & {$[0.25]$} & {$[0.18]$} \\
\hline \multirow[t]{2}{*}{$(T / L)_{j}$ (reporting) } & $3.565^{* *}$ & $2.260^{* * *}$ & $-2.268^{* * *}$ & 0.060 & -0.724 & -0.836 & $-2.822^{* * *}$ \\
\hline & [1.49] & {$[0.54]$} & {$[0.86]$} & {$[0.26]$} & {$[0.73]$} & {$[0.72]$} & {$[0.75]$} \\
\hline \multirow[t]{2}{*}{ Constant } & -32.08 & $-50.21^{* * *}$ & $-19.29^{* *}$ & $-47.96^{* * *}$ & $-33.00^{* * *}$ & $-32.27^{* * *}$ & $-46.74^{* * *}$ \\
\hline & [26.5] & [2.95] & {$[9.60]$} & {$[8.14]$} & {$[6.61]$} & {$[9.24]$} & {$[10.7]$} \\
\hline Observations & 2034 & 2865 & 2831 & 2226 & 2858 & 2551 & 3138 \\
\hline$R$-squared & 0.73 & 0.83 & 0.88 & 0.78 & 0.84 & 0.80 & 0.90 \\
\hline $\begin{array}{l}F \text { test for Fixed } \\
\text { Effects }\end{array}$ & $2076^{* * *}$ & $77.20^{* * *}$ & $185.5^{* * *}$ & $975.6^{* * *}$ & $957.9^{* * *}$ & $7665^{* * *}$ & $180.6^{* * *}$ \\
\hline
\end{tabular}

the EU dummy variable are not statistically significant for Israel and Jordan, while for Egypt the estimated parameter is statistically significant but displays a negative sign. ${ }^{26}$

In the case of bilateral exports all estimated parameters on the EU dummy variables display negative signs and the majority of them are statistically significant. The estimated parameters are not statistically significant only for Egypt and Jordan - the countries that concluded their association agreements with the EU only recently and are the least integrated with the EU among the MENA countries as measured by the shares of their exports to the EU in their total exports.

Very similar results can be reported also for free trade agreements concluded 
with the EFTA countries. In the case of imports the only statistically significant and positive parameter estimate on the EFTA dummy variable is reported for Morocco while for the other countries parameter estimates are not statistically significant. In the case of exports all estimated parameters on this variable display negative signs and are statistically significant.

Interestingly, all the estimated coefficients on the indicator variables for free trade agreements with the Central and Eastern European EU candidate countries display positive signs both in the case of imports and exports and are statistically significant except for Israel in the case of exports. The estimated coefficients on the NAFTA dummy variable display negative signs in most cases but not all of them are statistically significant. The only positive and statistically significant coefficient on the NAFTA variable is reported for Jordan and only in the case of exports.

The parameter estimates obtained for intra-MENA plurilateral agreements always display positive signs but not all of them are statistically significant while in the case of bilateral intra-MENA agreements, especially those concluded by the future members of the Agadir group many parameters display negative signs and are highly statistically significant which evidences existing barriers to trade.

Summing up, these empirical results generally support the commonly made claims that trade liberalization among the MENA countries in the form of bilateral trade agreements that preceded the Agadir Agreement was insufficient and its effectiveness can be called into question. Nevertheless, we were able to demonstrate that they allowed at least some MENA countries, although not necessarily the future members of the Agadir group, to increase their bilateral trade flows.

\section{Concluding Remarks}

In this paper we have studied the effectiveness of the recent EU-sponsored trade liberalization in the MENA countries. We have found that while trade liberalization with the EU in the form of new Association Agreements was on average effective in raising their bilateral imports from the EU at the same time it did not contribute positively to the expansion of their exports to the EU. The negative and statistically significant coefficients on the EU indicator variables evidence the presence of trade restrictions on the MENA exports to the EU. This suggests that the EU member states are the main beneficiaries of the new EU Association Agreements, due to the opening of the MENA markets to industrial products from the EU while keeping 
the EU markets closed to imports of agricultural goods from the MENA countries. $^{27}$

Regrettably, the new Association Agreements did not bring any significant progress in the field of trade liberalization in agricultural goods in which the MENA countries have comparative advantage and where a strong unexploited trade potential exists. Moreover, the EU continues to subsidize its agricultural production through the costly and inefficient CAP which counterbalances comparative advantage of the MENA countries and by preventing full realization of the gains from trade hurts their economic development. Therefore, if the new Association Agreements are to exert a symmetric impact on bilateral trade flows between the EU and the MENA countries the EU countries should make their markets more open to agricultural imports from the MENA countries and allow them compete on an even playing field.

Another important issue is that vertical "hub and spoke" trade liberalization between the EU and the MENA countries in the form of Association Agreements if not complemented by horizontal trade liberalization among the MENA countries themselves might have adverse effects for the location and development of their industrial activity leading to increased unemployment in these countries as suggested by some new economic geography models. ${ }^{28}$ Therefore, future empirical studies should address this important issue by looking at the impact of asymmetric trade liberalization on investment creation and investment diversion in the MENA countries. $^{29}$

Moreover, while the majority of the EU Association Agreements have already entered into force horizontal trade liberalization among the MENA countries is still lagging behind. Therefore, it is to be hoped that the EU Association Agreements will spur far reaching trade liberalization in the MENA countries resulting in the creation of the regional FTA that would counterbalance or at least reduce the

\footnotetext{
${ }^{27}$ The effects of the Euro-Mediterranean Agreements on the third countries are not clear and deserve closer attention in future empirical studies. In particular, it is not clear whether the increase in the MENA imports from the EU comes at the expense of the suppliers of manufactured goods located in other OECD countries that did not conclude free trade agreements with the MENA countries. For example, Tovias (1997) argues that a part of the increase of imports from the EU may represent trade diversion against other OECD countries.

${ }^{28}$ See for example Puga and Venables (1997). Although their insights turned out not to be robust with respect to model assumptions as demonstrated in Baldwin et al. (2003) the potential threat still exists.

${ }^{29}$ For example, Jovanovic $(2005$, p.550) notices that "In spite of various good intentions, talks, meetings, declarations, hopes and promises EU private investors are not much interested in Southern Mediterranean countries".
} 
impact of "hub and spoke" trade liberalization with the EU. The Agadir Agreement is frequently seen as a stepping stone to the formation of such a regional trading agreement. However, given the delays in its implementation it is too early to evaluate its effectiveness. Therefore, trade liberalization among the Agadir group member countries deserves closer attention in future empirical studies.

\section{Acknowledgements}

The authors would like to thank anonymous referees, Jan Jakub Michalek, Alfred Tovias, and the participants at the EEFS 2007 conference in Sofia for their helpful comments and suggestions on the earlier draft of this paper. Financial support of the FEMISE grant no. FEM31-15 is gratefully acknowledged. The views presented here are those of the authors only and not the institutions they represent.

Received 25 October 2007, Revised 30 June 2008, Accepted 16 October 2008

\section{Appendix}

A1. Summary Statistics for the Whole MENA Sample

Import Sample

\begin{tabular}{ccccc}
\hline variable & Mean & Standard deviation & Min & Max \\
\hline Log(imports) & 8.222 & 3.403 & -2.874 & 16.320 \\
Log(GDPpartner) & 24.716 & 1.905 & 18.994 & 30.001 \\
Log(GDPreporter) & 25.284 & 0.958 & 22.963 & 26.960 \\
Log(T/Lpartner) & -1.787 & 0.899 & -3.221 & -0.562 \\
Log(T/Lreporter) & -1.757 & 1.239 & -8.339 & 1.169 \\
\hline
\end{tabular}

Export Sample

\begin{tabular}{ccccc}
\hline variable & Mean & Standard deviation & Min & Max \\
\hline Log(exports) & 7.612 & 3.376 & -2.150 & 16.405 \\
Log(GDPpartner) & 24.539 & 2.033 & 18.968 & 30.001 \\
$\log ($ GDPreporter $)$ & 25.314 & 0.945 & 22.963 & 26.960 \\
$\log ($ T/Lpartner $)$ & -1.829 & 0.919 & -3.221 & -0.562 \\
$\log (\mathrm{T} /$ Lreporter $)$ & -1.800 & 1.265 & -8.339 & 1.169 \\
\hline
\end{tabular}




\section{References}

Al-Atrash, H. and Yousef, T. (2000), "Intra-Arab Trade: Is It too Little?", IMF Working Paper No. 2000/10.

Augier, P. and Gasiorek, M. (2003), "The Welfare Implications of Trade Liberalization between the Southern Mediterranean and the EU", Applied Economics, 35, pp. 11711190.

Arnon, A., Spivak A., and Weinblatt, J. (1996), “The Potential for Trade between Israel, the Palestinians and Jordan”, World Economy, 19, pp. 113-134.

Baldwin, R., Forslid, R., Martin, P., Ottaviano, G.M. and Robert-Nicoud, F. (2003), Economic Geography and Public Policy, Princeton University Press, Princeton.

Banks, A.S., (ed.), (1995), Political Handbook of the World 1994-1995, CSA Publications, Binghamton, NY.

Broto, C., Ruiz, J. and Vilarrubia, J. (2006), "Firm Heterogeneity and Selection Bias: Estimating Trade Potential in the Euromed Region", Bank of Spain Working Paper, http://www.eco.uc3m.es/jruiz/research.

Cieslik, A. (2007), "Augmented Gravity Equation and Incomplete Specialization in Production", Warsaw University, Department of Economics Working Paper.

Deardorff, A.V. (1998), "Determinants of Bilateral Trade: Does Gravity Work in a Neoclassical World?", in: Frankel, J.A. (ed.), The Regionalization of the World Economy, The University of Chicago Press, Chicago.

de la Torre, A. and Kelly M. (1992), "Regional Trading Arrangements", IMF Occasional Paper No. 93.

Dennis, A. (2006), "The Impact of Regional Trade Agreements and Trade Facilitation in the Middle East North Africa Region", World Bank Policy Research Working Paper WPS 3873.

Ekholm, K., Torstensson, J. and Torstensson R. (1996), "The Economics of Middle East Peace Process; Are there Prospects for Trade and Growth?", World Economy, 19, pp. 555-574.

Evenett, S.J. and Keller, W. (2002), "On the Theories Explaining the Success of the Gravity Equation", Journal of Political Economy, 110, pp. 281-316.

Fischer, S. (1993), "Prospects for Regional Integration in the Middle East", in: de Mello J. and Panagariya A. (eds.) New Dimensions in Regional Integration, Cambridge University Press, Cambridge.

Frankel, J.A. (1997), Regional Trading Blocs in the World Economic System, Institute for International Economics, Washington, D.C.

Helpman, E. (1981), "International Trade in the Presence of Product Differentiation, Economies of Scale and Monopolistic Competition: a Chamberlin-Heckscher-Ohlin Approach", Journal of International Economics, 11, pp. 305-340.

Jones, R.W. (1965), "The Structure of Simple General Equilibrium Models", Journal of Political Economy, 73, pp. 557-572. 
Jovanovic, M.N. (2005), The Economics of European Integration: Limits and Prospects, Edward Elgar, Cheltenham.

Maskus, K.E. and Konan, D.E. (1997), "Trade Liberalization in Egypt", Review of Development Economics, 1, pp. 275-293.

Matyas, L. (1997), "Proper Econometric Specification of the Gravity Model", World Economy, 20, pp. 363-368.

Nugent, J.B. and Yousef, T.M. (2005), "Does MENA Defy Gravity? How MENA has Performed in its Intraregional, EU and Other Trade: Implications for EU and IntraMENA Trade Arrangements", EUI Working Paper No. 2005/26.

Peridy, N. (2005), "The Trade Effects of the Euro-Mediterranean Partnership: What are the Lessons for ASEAN Countries?", Journal of Asian Economics, 16, pp. 125-139.

Puga, D. and Venables, A. (1997), "Preferential Trading Arrangements and Industrial Location", Journal of International Economics, 43, pp. 347-368.

Rutherford, T.J., Rutstrom, E.E. and Tarr, D. (1993), "Morocco's Free Trade Agreements with the European Community", World Bank Policy Research Working Paper WPS 1173.

Söderling, L. (2005), "Is the Middle East and North Africa Region Achieving Its Trade Potential?", IMF Working Paper No. 2005/90.

Tovias, A. (1977), Tariff Preferences in Mediterranean Diplomacy, Macmillan, London.

Tovias, A. (1997), "The Impact of the Euro-Mediterranean Free Trade Area Initiative on Mediterranean Non-Member Countries", Mediterranean Politics, 2, pp. 113-128.

Tovias, A., Kalaycioglu, S., Dafni, I., Ruben, E., and Herman, L. (2007), "What Would Normalization of Economic Relations between Mashrek Countries, Turkey and Israel Imply?", World Economy, 30, pp. 665-684.

World Bank (2006), World Development Indicators, World Bank, Washington, D.C. 